\title{
Enhanced removal of nitrate in an integrated electrochemical- adsorption system
}

Mahatheva Kalaruban ${ }^{1}$, Paripurnanda Loganathan ${ }^{1}$, Jaya Kandasamy ${ }^{1}$, Ravi Naidu ${ }^{2}$,

Saravanamuthu Vigneswaran ${ }^{1 *}$,

${ }^{1}$ Faculty of Engineering, University of Technology Sydney (UTS), P.O. Box 123, Broadway, NSW 2007, Australia

${ }^{2}$ CRC CARE, University of Newcastle, Callaghan, 2308, NSW, Australia

*Corresponding author. Tel.:+612 95142641, fax: +61295142633.

Email: s.vigneswaran@uts.edu.au

\begin{abstract}
The electrochemical (EC) method of removing pollutants in water is a widely used process in water and wastewater treatment. An EC-adsorption integrated system was investigated to test whether the simultaneous removal of nitrate by the two processes would be better than removal utilising the individual EC and adsorption methods. In the integrated system, an adsorbent (ion exchange resin - Dowex 21k XLT) was placed inside a stainless steel box that served as an anode with a $\mathrm{Cu}$ plate as cathode. In an experiment using $2 \mathrm{~L}$ nitrate solution containing $20 \mathrm{mg} \mathrm{N} / \mathrm{L}$ and $2 \mathrm{~g}$ adsorbent the rate of nitrate removal in the integrated system was initially fast with $35 \%$ removed in $30 \mathrm{~min}$, though slowing down later. The rate of removal increased with increasing current, voltage and $\mathrm{pH}$ up to 7 but decreased as the distance between the electrodes also increased. The optimum nitrate removal of $67 \%$ was obtained at

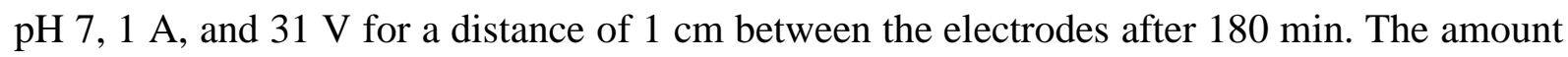


of nitrate removed fell when sulphate was present in the integrated system due to sulphate competing with nitrate for adsorption. Concentration of ammonium produced by nitrate reduction in the EC system was reduced in the presence of adsorbent. Nitrate removal in the integrated system is approximately equal to the sum of the removals in the two individual processes.

Key words: Nitrate, electrochemical treatment, adsorption, electrodes, ion exchange resin

\section{Highlights}

- Stainless steel box with adsorbent acted as anode in an electrochemical (EC) cell.

- Nitrate removal: combined EC-adsorption system $\approx$ adsorption system + EC system.

- Nitrate removal was highest at $\mathrm{pH} 7,1 \mathrm{~cm}$ electrodes-apart, $1 \mathrm{~A}$, and $30 \mathrm{~V}$.

\section{Introduction}

The electrochemical (EC) method is a widely used process for water and wastewater treatment. It is an environmentally friendly treatment technology for removing nitrate and a wide range of pollutants with less sludge production and less use of chemicals [1,2]. In this treatment method, nitrate ions are converted to $\mathrm{N}_{2}$ gas at the cathode as the major product and released into the environment [3]. Other pollutants such as ammonia [4], oil [5], dye [6], heavy metals [7], viruses [8], E-Coli [9], turbidity [10], phosphate [11], and fluoride [12] can also be removed from water through this method. This technology is fairly inexpensive to operate and the cost can be further reduced if renewable energy sources are employed. Although this method has several advantages, it also has some disadvantages such as metal oxide formation on the cathode and the need to regularly replace sacrificial electrodes.

The EC process has been used at several locations for ground water nitrate treatment [13]. Electro-reduction of nitrate has been studied over the last few decades using electrodes of 
metals such as $\mathrm{Ni}, \mathrm{Fe}, \mathrm{Al}, \mathrm{Zn}, \mathrm{Au}, \mathrm{Pt}, \mathrm{Pd}, \mathrm{Ag}, \mathrm{Cu}, \mathrm{Ru}$, and Rh [14-19]. Of these metals, $\mathrm{Cu}$ emerged as the best cathode for reducing nitrate [14, 19]. A stainless steel plate has been employed in previous studies for the removal of nitrite [10], nitrate [20] and ammonia [21]. In the nitrite removal study, stainless steel served as both the cathode and anode electrodes while in the studies on ammonium and nitrate removal it was used only as the cathode and other metals such as conductive diamond and $\mathrm{TiO}_{2}$ were used as anode.

Although the nitrate decomposes to harmless nitrogen gas as the main product at the cathode, low concentrations of some by-products such as ammonia and nitrite may also be produced in the solution [22]. Consequently, the ammonia is oxidised to nitrogen gas at the anode [23]. If chloride ions are present in the water they are also oxidised at the anode as chlorine gas, which dissolves in water to produce hypochlorite. The hypochlorite reacts with the ammonia/ammonium ions to produce nitrogen gas [3]. In the study by Li et al. [23] nitrite or ammonia was not detected in the final solution due to the presence of chloride ions.

The possible reactions at the cathode are as follows [23,24]:

Nitrate reduction to $\mathrm{N}_{2}, \mathrm{NH}_{3}, \mathrm{NO}_{2}^{-}$

$\mathrm{NO}_{3}{ }^{-}+3 \mathrm{H}_{2} \mathrm{O}+5 \mathrm{e} \rightarrow 1 / 2 \mathrm{~N}_{2}+6 \mathrm{OH}^{-}$

$\mathrm{NO}_{3}{ }^{-}+6 \mathrm{H}_{2} \mathrm{O}+8 \mathrm{e} \rightarrow \mathrm{NH}_{3}+9 \mathrm{OH}^{-}$

$\mathrm{NO}_{3}{ }^{-}+\mathrm{H}_{2} \mathrm{O}+2 \mathrm{e} \rightarrow \mathrm{NO}_{2}^{-}+2 \mathrm{OH}^{-}$

Nitrite reduction to $\mathrm{N}_{2}, \mathrm{NH}_{3}, \underline{\mathrm{NH}_{2}} \underline{\mathrm{OH}}$

$\mathrm{NO}_{2}^{-}+2 \mathrm{H}_{2} \mathrm{O}+3 \mathrm{e} \rightarrow 1 / 2 \mathrm{~N}_{2}+4 \mathrm{OH}^{-}$

$\mathrm{NO}_{2}^{-}+5 \mathrm{H}_{2} \mathrm{O}+6 \mathrm{e} \rightarrow \mathrm{NH}_{3}+7 \mathrm{OH}^{-}$

$\mathrm{NO}_{2}^{-}+4 \mathrm{H}_{2} \mathrm{O}+4 \mathrm{e} \rightarrow \mathrm{NH}_{2} \mathrm{OH}+5 \mathrm{OH}^{-}$

Hydrogen evolution is the main parasitic cathodic reaction (equation 7) [24]

$2 \mathrm{H}_{2} \mathrm{O}+2 \mathrm{e} \rightarrow \mathrm{H}_{2}+2 \mathrm{OH}-$ 
The possible reactions at the anode are [25]:

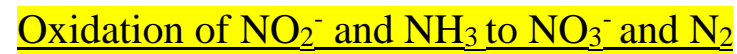

$\mathrm{NO}_{2}{ }^{-}+\mathrm{H}_{2} \mathrm{O} \rightarrow \mathrm{NO}_{3}{ }^{-}+2 \mathrm{H}^{+}+2 \mathrm{e}$

$2 \mathrm{NH}_{3} \rightarrow \mathrm{N}_{2}+6 \mathrm{H}^{+}+6 \mathrm{e}$

Oxygen evolution is the main anodic reaction (equation 10) [24]

$2 \mathrm{H}_{2} \mathrm{O} \rightarrow \mathrm{O}_{2}+4 \mathrm{H}^{+}+4 \mathrm{e}$

The following is a possible reaction at the anode when $\mathrm{Cl}^{-}$ions are present in the water:

$2 \mathrm{Cl}^{-} \rightarrow \mathrm{Cl}_{2}+2 \mathrm{e}^{-}$

The $\mathrm{Cl}_{2}$ produced according to equation 11 immediately reacts with water to form hypochlorite ( $\mathrm{HClO})$ (equation 12) which would react with ammonia to produce nitrogen gas (equation 13) $[22,23]$. This would reduce the concentration of $\mathrm{NH}_{4}^{+}$produced by the EC reduction of $\mathrm{NO}_{3}{ }^{-}$.

$\mathrm{Cl}_{2}+\mathrm{H}_{2} \mathrm{O} \rightarrow \mathrm{HClO}+\mathrm{H}^{+}+\mathrm{Cl}^{-}$

$2 \mathrm{NH}_{4}^{+}+3 \mathrm{HClO} \rightarrow \mathrm{N}_{2}+3 \mathrm{H}_{2} \mathrm{O}+5 \mathrm{H}^{+}+3 \mathrm{Cl}^{-}$

Despite the fact that several studies have reported the removal of nitrate using EC technology [24-27], only one analysis investigated the removal of nitrate using an integrated EC-adsorption system. In that study, a carbon anode electrode was coated with a nitrate selective BHP55 ion exchange resin and used for nitrate and chloride removal [28]. The nitrate and chloride removals were 19 and $15 \mathrm{mmol} / \mathrm{m}^{2}$ from solutions containing $2 \mathrm{mM}$ and $5 \mathrm{mM}$ chloride, respectively. However, the relative contribution of resin adsorption and EC in nitrate removal was not reported. Coating the electrode with the adsorbent may not produce its full potential of removing nitrate because parts of the electrode and adsorbent may not be available to actively remove nitrate. Instead of coating the electrode with the adsorbent, the adsorbent can be retained in suspension near the electrode inside a box to produce the full potential of the adsorbent and the electrode in removing nitrate. The study reported in this paper is based on having a stainless steel electrode box as the anode with the box containing an adsorbent. The main objectives of the research were to: (i) study the efficiency in removing nitrate using the 
integrated EC-adsorption system and compare the removal with the same technologies when they are used separately; and (ii) investigate the effects of operating conditions such as $\mathrm{pH}$, voltage, current, and distance between electrodes on the removal of nitrate with and without the presence of co-ions sulphate and phosphate.

\section{Experimental details}

\subsection{Materials and methods}

An anion exchange resin Dowex 21k XLT was used in this integrated system. In the EC system, Cu plate and stainless steel sieve box were used as cathode and anode electrode, respectively. The dimensions of the $\mathrm{Cu}$ plate were $11 \mathrm{~cm}$ x $6 \mathrm{~cm} \times 0.5 \mathrm{~cm}$ and the dimensions of the submerged part of the plate inside the solution were $9 \mathrm{~cm} \times 6 \mathrm{~cm} \times 0.5 \mathrm{~cm}$. A stainless steel (304) sieve with an aperture size of $0.25 \mathrm{~mm}$ was employed to make the electrode box. The dimensions of the submerged part of the box inside the solution were $9 \mathrm{~cm} \times 6 \mathrm{~cm} \times 2 \mathrm{~cm}$. A feed solution containing nitrate was prepared by dissolving ANALAR grade $\mathrm{KNO}_{3}$ in tap water to obtain a concentration of $20 \mathrm{mg} \mathrm{N} / \mathrm{L}$. Tap water had chloride, sulphate and phosphate concentrations of $30 \mathrm{mg} \mathrm{Cl} / \mathrm{L}, 1.1 \mathrm{mg} \mathrm{S} / \mathrm{L}$ and $1 \mathrm{mg} \mathrm{P} / \mathrm{L}$, respectively. For the ion competition studies, ANALAR grade $\mathrm{KH}_{2} \mathrm{PO}_{4}$ and $\mathrm{Na}_{2} \mathrm{SO}_{4}$ were added to the nitrate solution to produce the required concentrations of phosphate and sulphate.

In each experiment, $2 \mathrm{~g}$ adsorbent was packed inside the stainless steel sieve box (anode electrode) and immersed in a $2 \mathrm{~L}$ solution in parallel with the $\mathrm{Cu}$ plate (Fig. 1). The EC and adsorption experiments were conducted individually using the same conditions to compare the advantage of the integrated system over the individual systems. A magnetic stirrer rotating at a speed of $120 \mathrm{rpm}$ was used at the bottom of the container to keep the adsorbent in suspension and to maintain the solution at a uniform concentration. A Powertech MP 3086 model AC to DC converter provided direct current to the EC system. The voltage/current was measured in 
the converter. The performance of the EC and the integrated systems were studied in terms of nitrate removal at different distances between the electrodes $(0.5,1,2$ and $3 \mathrm{~cm})$, voltage $(15$, $20,25$, and $30 \mathrm{~V})$, current $(0.2,0.5,0.7$, and $1 \mathrm{~A})$ and $\mathrm{pH}(3,5,7,9$, and 11$)$. All the experiments were conducted at the room temperature of $25-27^{0} \mathrm{C}$.

\subsection{Chemical analysis}

Nitrate, phosphate, and sulphate concentrations were analysed by an ion chromatograph (Model 790 Personal IC) equipped with an auto sampler and a conductivity cell detector. The ion chromatograph was cleaned before the analysis using a mobile phase solution $\left(\mathrm{Na}_{2} \mathrm{CO}_{3}\right.$, $\mathrm{NaHCO}_{3}$ ), diluted sulphuric acid and Milli-Q water. Ammonium ion concentration was measured using a HACH DR 3900 test kit. The solutions' pH was measured using an HQ40d portable $\mathrm{pH}$ meter. The dissolved Fe ions concentration was measured using a Microwave Plasma-Atomic Emmison Spectrometer (Agilent 4100 MP-AES). 


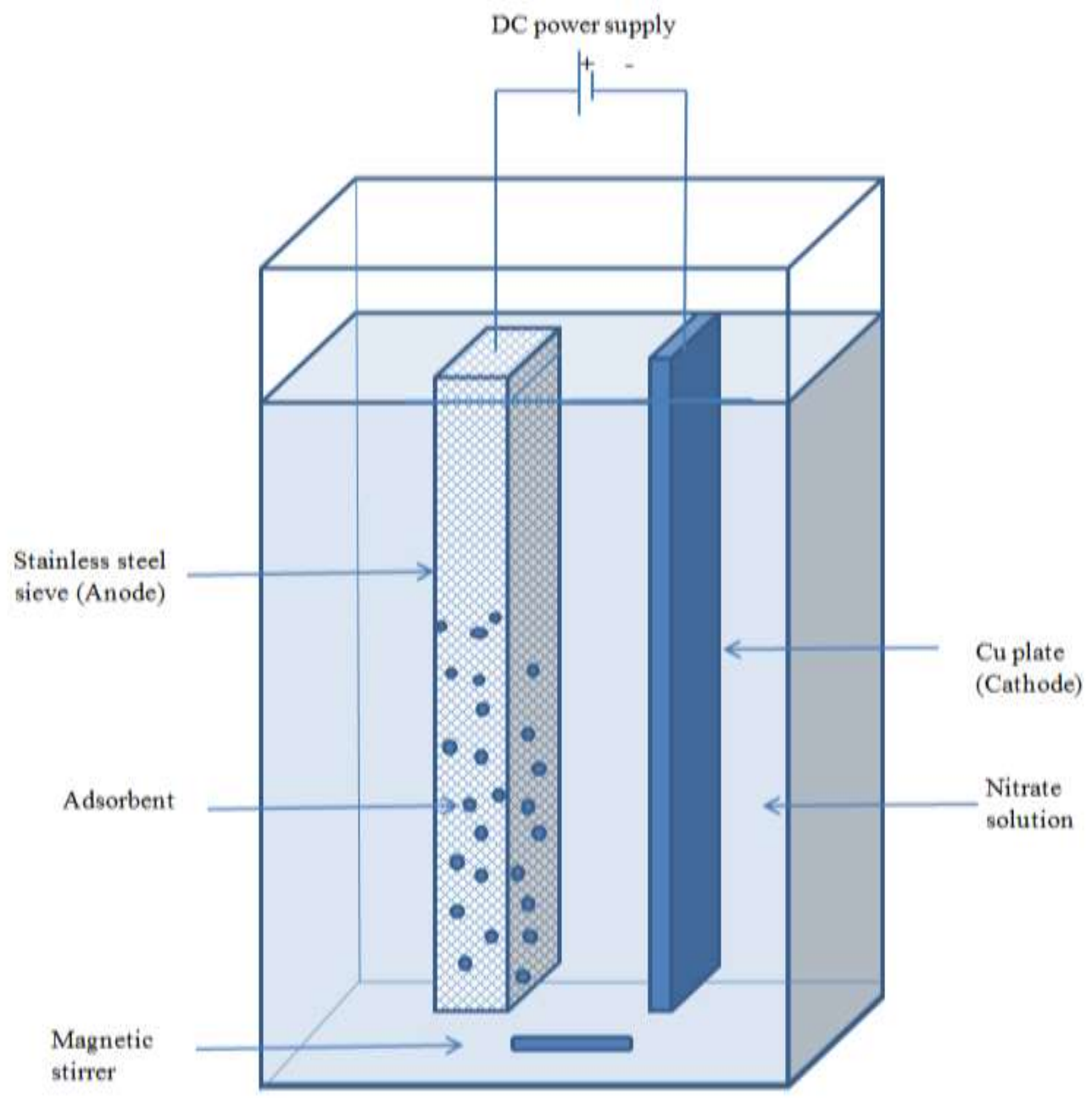

Fig. 1. Integrated EC-adsorption system 


\section{Results and discussion}

\subsection{Effect of distance between electrodes}

The current decreased from 1.3 A to $0.2 \mathrm{~A}$ as the distance between the electrodes increased at a constant voltage of $30 \mathrm{~V}$. The nitrate removal increased when the distance between the electrodes for both the EC system and integrated system shortened (Fig. 2). The reason for this is that when the gap between electrodes narrows, the resistance between the electrodes reduced and the current increased [29]. Thus, the rate of nitrate reduction at the cathode increased and reduced forms of nitrogen species were produced (Eq 1 - Eq 7). In the integrated system, in addition to the reduction of nitrate at the cathode, the nitrate that moved to the anode was adsorbed on to the adsorbents.

Some of the nitrates in the solution were reduced to ammonia at the cathode (Eq 2) However, the chloride in the solution which originated from the tap water used in the experiment was oxidised to hypochlorite and the hypochlorite oxidised the ammonium in the solution to nitrogen gas (Eq 11, 12, and 13). The percentage of nitrate removed in the integrated system was almost equal to the sum of the removals in the adsorption and EC system. The highest removal efficiency of $68 \%$ was achieved at $0.5 \mathrm{~cm}$ distance between electrodes distance and this was only marginally higher than that at $1 \mathrm{~cm}$ electrode distance $(67 \%)$. However, the power consumption (voltage $\mathrm{x}$ current $\mathrm{x}$ time) for the 0.5 cm electrodes distance $(1.3 \mathrm{~A} \times 30 \mathrm{~V} \times 3 \mathrm{~h})$ was higher $(0.12 \mathrm{kWh})$ than that for $1 \mathrm{~cm}$ electrodes distance ( $1 \mathrm{~A} \times 30 \mathrm{~V} \times 3 \mathrm{~h}=0.09 \mathrm{kWh})$. Therefore, to avoid the higher cost due to increased power consumption the remaining experiments were conducted using 1 cm electrode distance.

The ammonium concentration in the final solution increased with distance between the electrodes for the EC ( 0.12 to $0.64 \mathrm{mg} / \mathrm{L})$ and integrated $(0.01$ to $0.25 \mathrm{mg} / \mathrm{L})$ 
systems. The increase in ammonium concentration was due to only a limited amount of hypochlorite being available in the solution to oxidise ammonium. Hypochlorite limitation was due to the low current values at large distances between electrodes; the low current values were not enough to oxidise the chloride to hypochlorite. This explanation is consistent with the results documented by Vanlangendonck et al. [21] where decreased current reduced the ammonium oxidation rate.

It is interesting to note that the amount of ammonium ion in solution was lower in the integrated system than in the EC system. This is probably due to the chloride released from the adsorbents during nitrate adsorption $[30,31]$ in addition to the chloride present in tap water. The higher concentration of chloride in the system would have produced a larger concentration of hypochlorite, which oxidised greater amounts of ammonium ions resulting in lower ammonium concentration in solution (Eq 11, 12 and 13). 
(A)

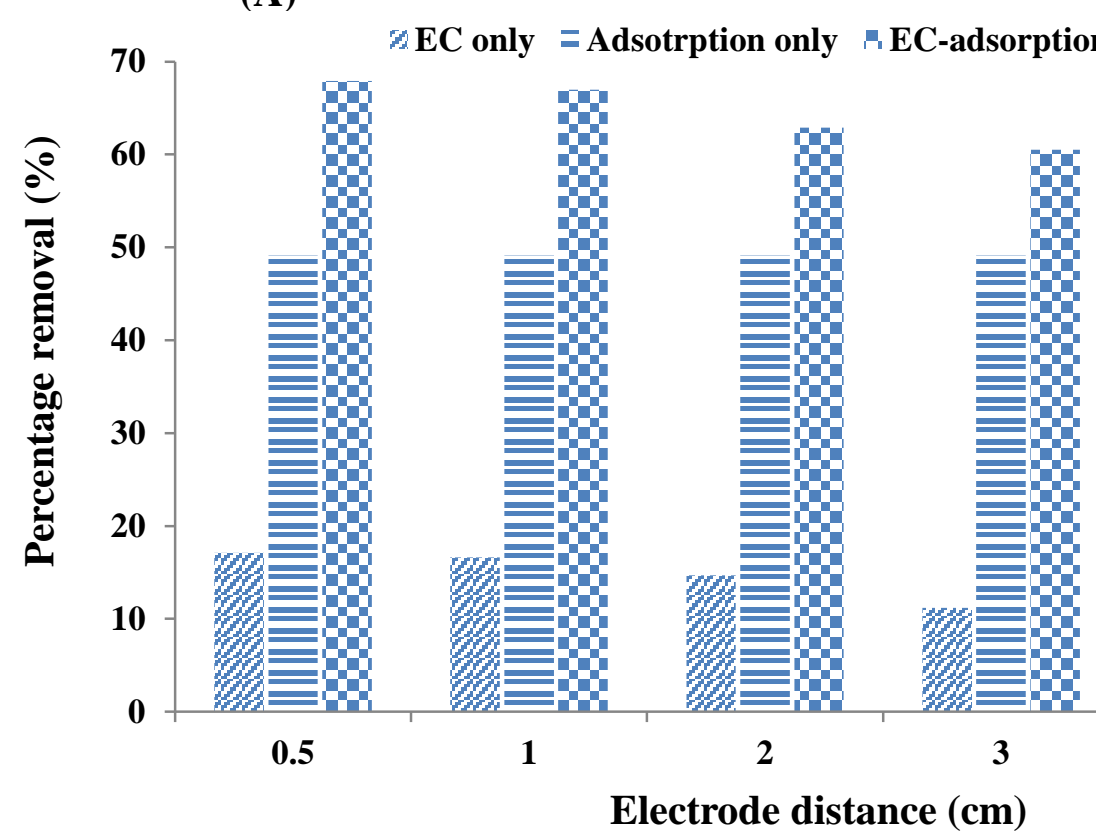

(B)

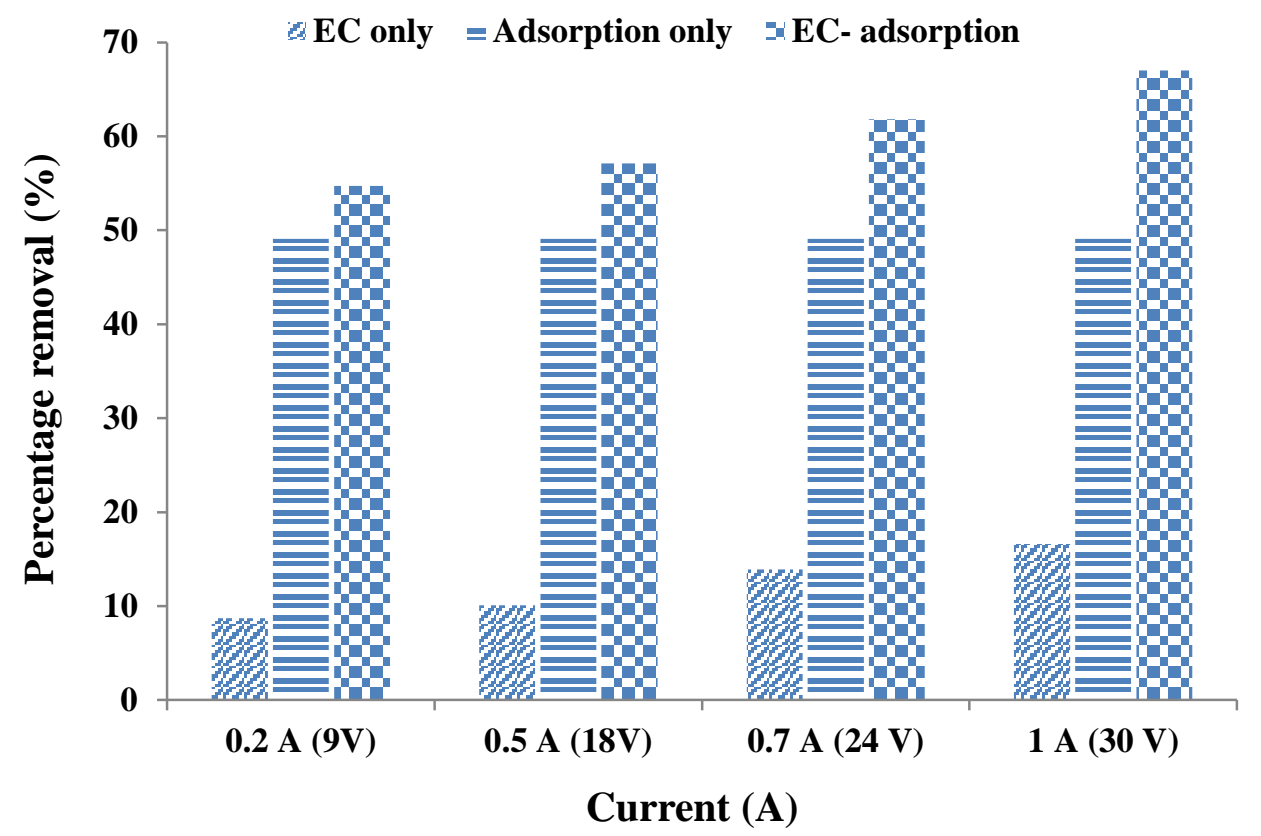

Fig. 2. Percentage of nitrate removal with (A) increasing distance between electrodes and (B) increasing current (volume of solution- 2 L, amount of adsorbent $2 \mathrm{~g}$ and initial nitrate concentration $20 \mathrm{mg} \mathrm{N} / \mathrm{L}$ ). 


\subsection{Effect of current}

The effect of current on nitrate removal was investigated using the current values of $0.2,0.5,0.7$ and $1 \mathrm{~A}$ with $1 \mathrm{~cm}$ distance between the electrodes at $\mathrm{pH} 7$. The voltages increased automatically while increasing the current and the values were 9, 18, 24 and 30 $\mathrm{V}$ for the current values of $0.2,0.5,0.7$ and $1 \mathrm{~A}$, respectively. The percentages of nitrate removal increased with current for the EC and integrated systems (Fig. 2). The increased current would have enhanced the oxidation-reduction reaction rate at the electrodes [21]. Therefore, at higher current, a larger percentage of nitrate was converted to $\mathrm{N}_{2}$ or $\mathrm{NH}_{3}$ gas $/ \mathrm{NH}_{4}{ }^{+}$(Eq 1-6) resulting in reduced nitrate concentration in the solution [26].

The economics of the nitrate removal process should also be considered. The total power consumption (current $\mathrm{x}$ voltage $\mathrm{x}$ time) rose with the increase in current and they were $0.005,0.027,0.050$, and $0.090 \mathrm{kWh}$ for the current of $0.2,0.5,0.7$ and $1 \mathrm{~A}$ for $3 \mathrm{~h}$ operation, respectively. For the EC system, the percentage of nitrate removed for the lowest current of $0.2 \mathrm{~A}$ and the highest current of $1 \mathrm{~A}$ were $8.7 \%$ and $16.6 \%$ (3.44 and $6.34 \mathrm{mg}$ ), respectively. These values correspond to $8.7 \%$ and $16.6 \%$ nitrate removals. The cost of removing $1000 \mathrm{mg} \mathrm{N}$ was calculated in proportion to the cost of removing the amount of nitrate in the experiment. The costs for the highest and lowest currents were $\mathrm{A} \$ 4.26$ and $\mathrm{A} \$ 0.48$, respectively, for the removal of $1000 \mathrm{mg} \mathrm{N}$ (cost = current $\mathrm{x}$ voltage $\mathrm{x}$ operation time $\mathrm{x} \mathrm{A} \$ 0.3 / \mathrm{kWh}$ [32] for $\mathrm{EC}$ and $\mathrm{A} \$ 50 / \mathrm{kg}$ [33] for ion exchange resin). This calculation did not include labour and equipment costs. In the integrated system most of the nitrate removal occurred due to adsorption. Also, the adsorbent cost is much higher than the cost of electricity in the integrated system. Therefore, although the EC cost was much higher at the higher current, the total cost of the integrated system was almost equal for both the current values in the integrated system values; they were $A \$ 5.14$ and $A \$ 5.03$ for $1 \mathrm{~A}$ and $0.2 \mathrm{~A}$, respectively. In the integrated system, the amount of nitrate removal 
was $12 \%$ higher for the highest current (1 A) compared to the lowest current $(0.2 \mathrm{~A})$ (Fig. 2).

The ammonium concentration in the solution declined when the current increased, probably due to the elevated rate of hypochlorite formation by the oxidation of chloride in the solution (Eq 11 and 12). This would have reacted with ammonia/ammonium ions to release nitrogen gas (Eq 13). 


\subsection{Effect of $p H$}

The effect of $\mathrm{pH}$ on nitrate removal was investigated at $\mathrm{pHs}$ of 3, 5, 7, 9 and 11 with $1 \mathrm{~cm}$ distance between the electrodes, $1 \mathrm{~A}$ and 25-30 V; results are presented in Fig. 3. To adjust the $\mathrm{pH}$, diluted hydrochloric acid $(\mathrm{HCl})$ and diluted sodium hydroxide $(\mathrm{NaOH})$ were used, and therefore the ionic concentration would have increased in the

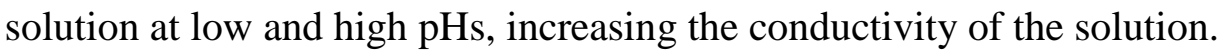

The removal of nitrate by Dowex was slightly high at low $\mathrm{pH}$ due to the protonation of the Dowex surface and above 7 it decreased due to the repulsion of nitrate ions by the negatively charged surface of Dowex and competition from increased $\mathrm{OH}^{-}$ concentration for adsorption. In the EC system, less nitrate was removed compared to the adsorption system but was nearly the same at all $\mathrm{pH}$ levels. The integrated system percentage of nitrate removal was equal to the sum of adsorption and EC systems percentages removal for $\mathrm{pH} 7$ - 11; it was, however, lower than the sum for $\mathrm{pH}$ less than 7. This may be due to the competition from $\mathrm{OH}^{-}$produced at low $\mathrm{pH}$, as a result of increased hydrogen evolution at the cathode, with nitrate for adsorption on Dowex (Eq 7). Li et al. [34] also reported that hydrogen evolution increased with decreasing $\mathrm{pH}$ resulting in the release of more $\mathrm{OH}^{-}$ions in the $\mathrm{EC}$ system which comprised the $\mathrm{Fe}$ cathode and $\mathrm{Ti} / \mathrm{IrO}_{2}-\mathrm{Pt}$ anode. The optimum $\mathrm{pH}$ for nitrate removal in the integrated system was $\mathrm{pH} 7$.

The ammonium ion concentration in the solution after $3 \mathrm{~h}$ was in the range of 0.1 $0.5 \mathrm{mg} / \mathrm{L}$ for the EC system and $0.01-0.05 \mathrm{mg} / \mathrm{L}$ for the integrated system for all $\mathrm{pHs}$. The low ammonium ion concentration in the integrated system is probably due to the release of chloride from Dowex during nitrate adsorption and the released chloride being converted to hypochlorite, which oxidised the ammonium (Eq 13). 


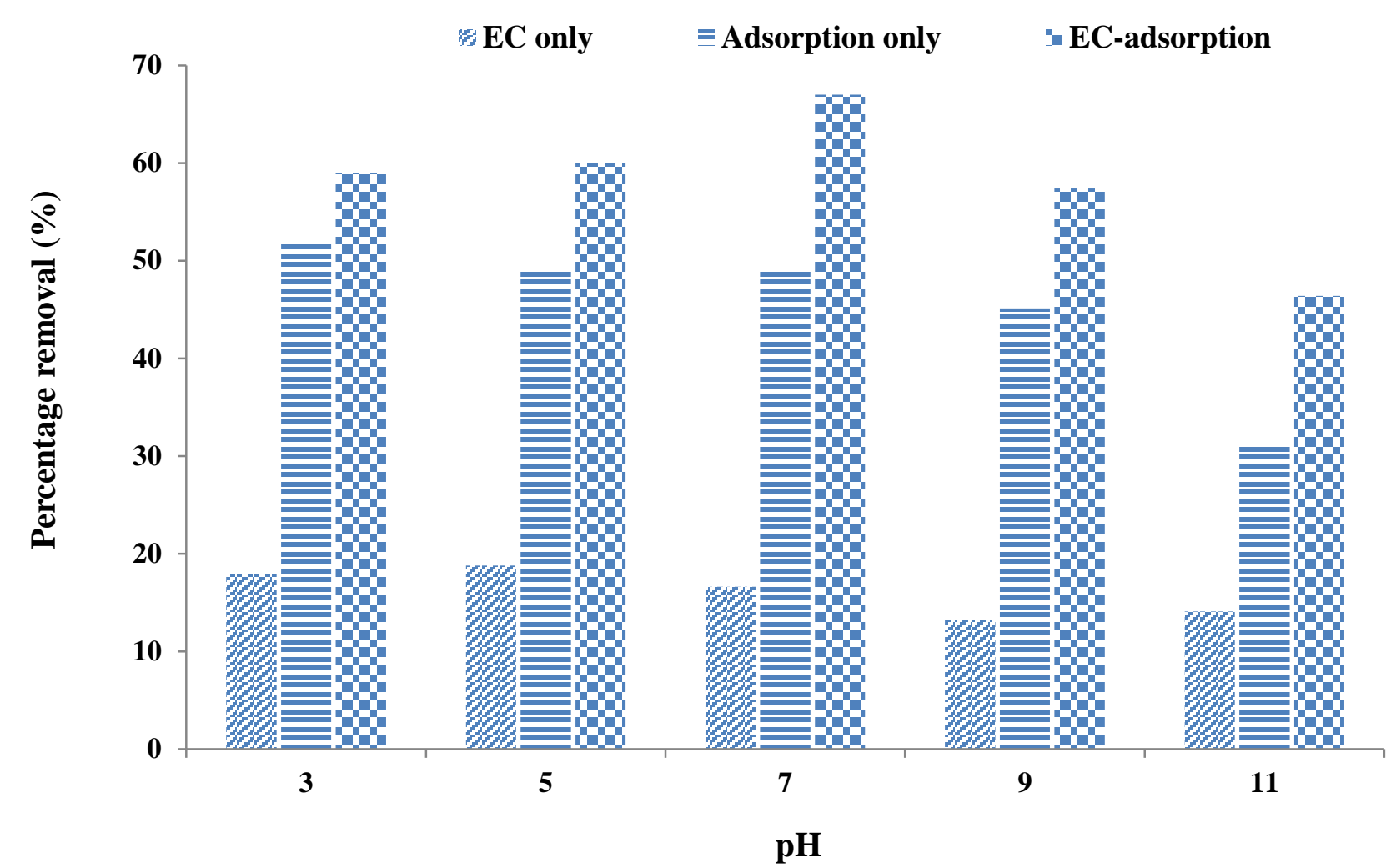

Fig. 3. Percentage of nitrate removed with change of $\mathrm{pH}$ (volume of solution- $2 \mathrm{~L}$, amount of adsorbent $2 \mathrm{~g}$ and initial nitrate concentration $20 \mathrm{mg} \mathrm{N} / \mathrm{L}$ ). 


\subsection{Effect of time}

The study on the kinetics of nitrate removal was conducted at the optimum conditions of nitrate removal of $\mathrm{pH} 7,1 \mathrm{~cm}$ distance between the electrodes, $1 \mathrm{~A}$ and $30 \mathrm{~V}$. The cumulative nitrate removal increased with time in all the three systems (Fig. 4). In the EC system, the nitrate removal was faster at the start but very much slowed down after $1 \mathrm{~h}$, probably due to the decrease in cathode activity of the $\mathrm{Cu}$ electrode with time. Paidar et al. [24] reported that though $\mathrm{Cu}$ cathode material has high electrocatalytic activity for nitrate reduction, it can get deteriorated by cathode polarisation. In their experiment on EC reduction of nitrate using $\mathrm{Cu}$ cathode, nitrate reduction markedly slowed down after three hours compared to the treatment with $\mathrm{Cu}$ addition where nitrate reduction was much higher. According to them, activation of the $\mathrm{Cu}$ electrode can be achieved by adding $\mathrm{Cu}$ salts to the solution which produces fresh $\mathrm{Cu}$ deposition on the cathode. On the other hand, Filimonov and Shcherbakov [35] attributed the increase of nitrate reduction caused by $\mathrm{Cu}$ salt addition to cuprous ions that form as an intermediate product in the course of electrochemical reduction of cupric cations. The cuprous ions were reported to have acted as a catalyst in the nitrate reduction.

Li et al. [23] also reported that nitrate reduction rate drastically reduced three hours after commencement of their EC experiment on nitrate reduction using $\mathrm{Cu} / \mathrm{Zn}$ electrode. In both the studies of Li et al. [23] and Paidar et al. [24], the decrease in activity of the $\mathrm{Cu}$ electrode was considered to be mainly due to the formation of $\mathrm{CuH}$ or $\mathrm{CuH}_{2}$ on the surface of the $\mathrm{Cu}$ electrode. Pérez-Gallent et al. [36] also attributed the deactivation of $\mathrm{Cu}$ electrode during nitrate reduction as due to hydrogen adsorption. In the study of $\mathrm{Li}$ et al. [23], the colour of the $\mathrm{Cu} / \mathrm{Zn}$ cathode changed to silvery white resulting in passivation of the electrode. This was reported to have caused by the selective dissolution of $\mathrm{Cu}$ during electrolysis. 
In the adsorption system, the number of vacant adsorption sites decreased with increased time resulting in a reduced rate of adsorption (Fig. 4) [30]. In the integrated system, both the electrode passivation and reduction in adsorption sites occurred with increased time causing a reduced nitrate removal rate (Fig. 4). The integrated system percentage removal was almost equal to the sum of the individual batch adsorption and EC system at all sampling times. The ammonium ion concentration was measured at every $1 \mathrm{~h}$ interval and it was observed that, for the EC system, it increased continuously and reached $0.26 \mathrm{mg} / \mathrm{L}$ at $3 \mathrm{~h}$. For the integrated system it remained almost the same in the $0.01-0.02 \mathrm{mg} / \mathrm{L}$ range. The lower ammonium concentration in the integrated system might be due to the conversion of chloride ions released from the adsorbent during nitrate adsorption (by ion exchange process) to hypochlorite (equation 12), which reacted with ammonia/ammonium ions to produce nitrogen gas (equation 13). In the EC system, there was no adsorbent to release chloride ions into solution by exchanging with nitrate in solution and therefore the ammonium/ammonia was not much lost as nitrogen gas as in the integrated system. 


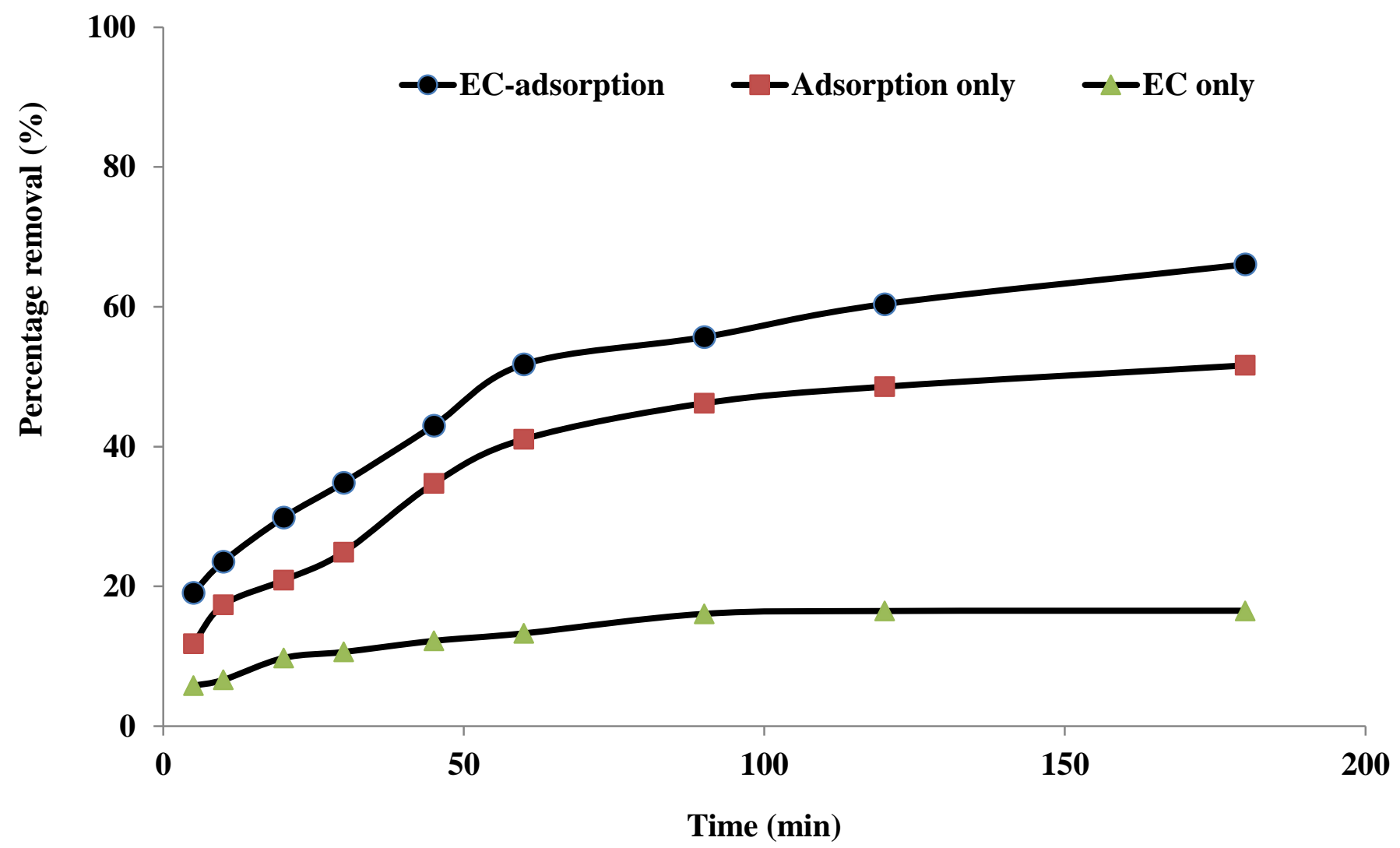

Fig. 4. Percentage removal of nitrate over time for the three nitrate removal systems (volume of solution- $2 \mathrm{~L}$, amount of adsorbent $2 \mathrm{~g}$ and initial nitrate concentration $20 \mathrm{mg} \mathrm{N} / \mathrm{L}$ ) 


\subsection{Effect of complementary ions}

\subsubsection{Effect of phosphate}

Phosphate's effect on nitrate removal was conducted with $20 \mathrm{mg} \mathrm{N} / \mathrm{L}$ and $5 \mathrm{mg}$ $\mathrm{P} / \mathrm{L}$ at pH 7 and with the conditions of $1 \mathrm{~A}$, and $28 \mathrm{~V}$; the results are presented in Fig. 5. A smaller concentration of phosphate than nitrate was used in the experiment to mimic the concentration differences of these ions normally found in surface and ground water. The nitrate removal percentage fell slightly in the presence of phosphate ions for all three systems. The previous batch and column adsorption experimental results also revealed that nitrate removal was reduced slightly in the presence of phosphate due to competition between the higher valent phosphate with lower valent nitrate for adsorption. The reduction in nitrate removal in the EC system may be because of electrode passivation from phosphate adsorbing on the anode or precipitating as $\mathrm{FePO}_{4}$ on the anode surface. A significant amount of $\mathrm{Fe}$ ions was found in the solution during the $\mathrm{EC}$ process due to the dissolution of the stainless steel sieve anode. The concentration of Fe ions in the solution was found to be $1.25 \mathrm{mg} / \mathrm{L}$ after $3 \mathrm{~h}$. The oxidation of $\mathrm{Fe}^{2+}$ ions occurs above $\mathrm{pH}$ 5 and therefore this oxidation is highly likely at the experimental $\mathrm{pH}$ of 7 [37]. Lacasa et al. [38] reported that in their EC system, $\mathrm{Fe}^{2+}$ ions were rapidly oxidised to $\mathrm{Fe}^{3+}$ ions. Assuming that the measured $\mathrm{Fe}$ concentrations were that of $\mathrm{Fe}^{3+}$ and converting the $\mathrm{Fe}$ ions concentrations in $\mathrm{mg} / \mathrm{L}$ to $\mathrm{mol} / \mathrm{L}$ unit, a calculation was made to determine whether precipitation of $\mathrm{FePO}_{4}$ occurred using the measured $\mathrm{Fe}\left(2.23 \times 10^{-5} \mathrm{M}\right)$ and $\mathrm{P}\left(1.6 \times 10^{-4}\right.$ M) concentrations. The calculation showed that $\left[\mathrm{Fe}^{3+}\right]\left[\mathrm{PO}_{4}{ }^{3-}\right]=3.59 \times 10^{-9}$. However, the solubility product of the $\mathrm{FePO}_{4}$ at $25^{0} \mathrm{C}$ is $1.3 \times 10^{-22}$ [39]. Therefore, $\left[\mathrm{Fe}^{3+}\right]\left[\mathrm{PO}_{4}{ }^{3-}\right]$ in the experimental solution was > Ksp which demonstrates that the phosphate was likely to have precipitated in the experiment as $\mathrm{FePO}_{4}$ in the solution or on the electrode's surface. 
Phosphate removal by EC was more than double that when using adsorption whereas nitrate removal was four times higher in adsorption than EC (Fig. 5). This difference between nitrate and phosphate removals supports the reasoning that phosphate was removed by precipitation, assisted by the EC process where Fe dissolute from the electrode reacted with phosphate. 


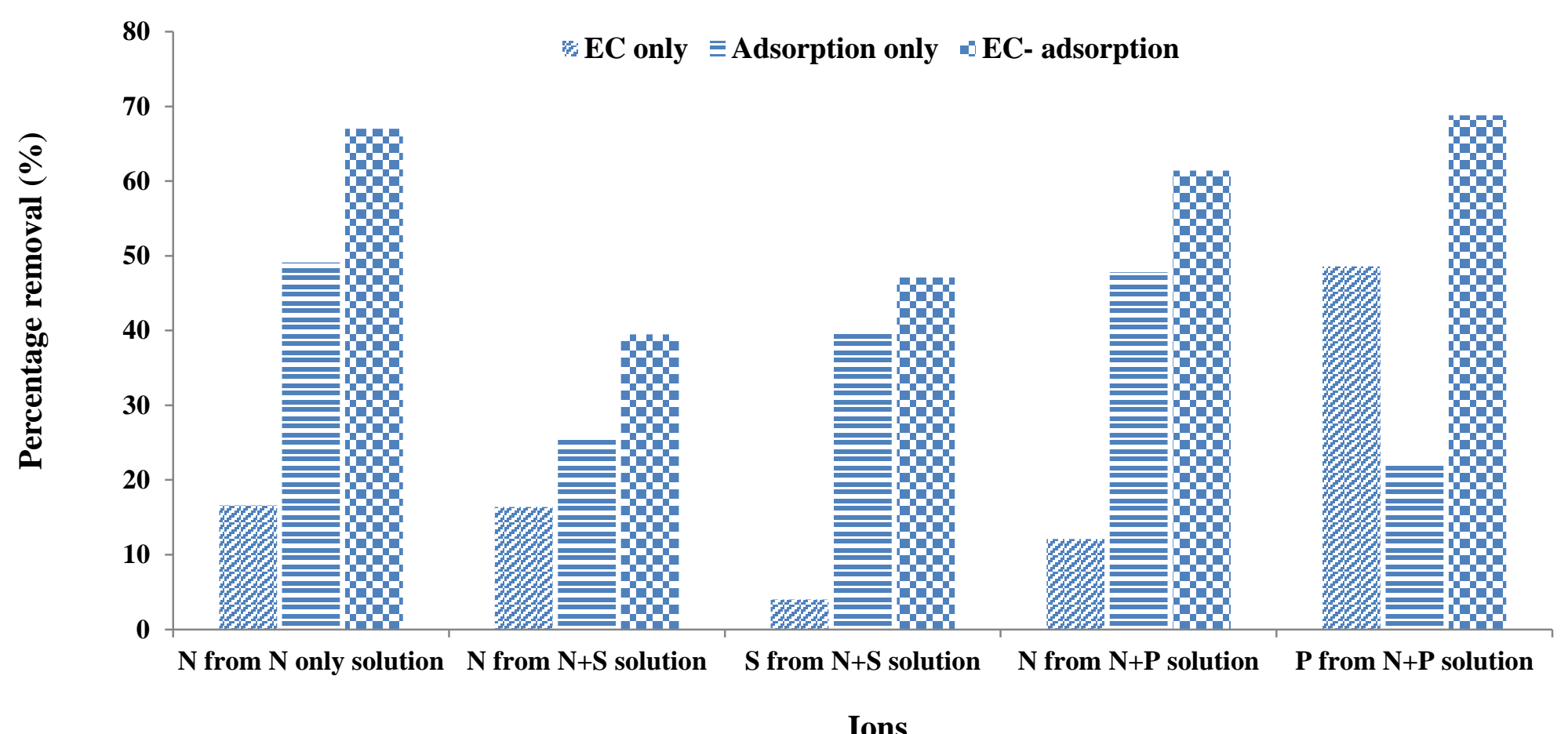

Fig. 5. Percentages of nitrate, phosphate and sulphate removed from solutions containing $\mathrm{N}$ only solution $(20 \mathrm{mg} \mathrm{N} / \mathrm{L}), \mathrm{N}+\mathrm{P}$ solution $(20 \mathrm{mg} \mathrm{N} / \mathrm{L}+5$ $\mathrm{mg} \mathrm{P} / \mathrm{L})$ and $\mathrm{N}+\mathrm{S}$ solution $(20 \mathrm{mg} \mathrm{N} / \mathrm{L}+50 \mathrm{mg} \mathrm{S} / \mathrm{L})$. Volume of solution $=2 \mathrm{~L}$, amount of adsorbent $=2 \mathrm{~g}$. 


\subsubsection{Effect of sulphate}

Sulphate's effect on nitrate removal was investigated in the presence of $50 \mathrm{mg} \mathrm{S} / \mathrm{L}$ and $20 \mathrm{mg} \mathrm{N} / \mathrm{L}$ at $\mathrm{pH}$ 7. The current was maintained at $1 \mathrm{~A}$ and the voltage fell from $30 \mathrm{~V}$ to $20 \mathrm{~V}$ due to the increased concentration of ions, as a result of adding high concentration of sulphate ions (Fig. 5). The increased ionic concentration decreased the resistance between the electrodes and elevated the electrical conductivity of the solution (conductivity $755 \mu \mathrm{S} / \mathrm{cm}$ compared to $427 \mu \mathrm{S} / \mathrm{cm}$ without adding sulphate); therefore, the voltage decreased. However, the nitrate removal was not influenced by the addition of sulphate ions in the EC system. On the other hand, adding sulphate reduced the removal of nitrate in the adsorption system and integrated system. The reduction in nitrate removal is probably due to the competition of sulphate with nitrate for adsorption. The previous batch and column adsorption studies indicated that sulphate ion intensively competed with nitrate due to its higher valence (two negative charges) than nitrate (one negative charge) ions [30]. A much higher percentage of sulphate than nitrate was adsorbed by the resin supporting the contention that sulphate competed with nitrate for adsorption (Fig. 5). The percentage of nitrate removed in the integrated system is approximately equal to the sum of the nitrate removed in the adsorption and EC systems. 


\subsubsection{Effect of phosphate and sulphate}

The phosphate and sulphate ions' competition with nitrate was tested in the presence of $5 \mathrm{mg} \mathrm{P} / \mathrm{L}$ phosphate and $50 \mathrm{mg} \mathrm{S} / \mathrm{L}$ sulphate. This solution contained $20 \mathrm{mg}$ $\mathrm{N} / \mathrm{L}$ of nitrate with the following conditions: $1 \mathrm{~cm}$ between electrodes, $1 \mathrm{~A}$ and $18 \mathrm{~V}$ (Fig. 6) at $\mathrm{pH}$ 7. In the presence of these co-ions the EC system's nitrate removal efficiency was not affected. However, the percentage of nitrate removed by adsorption on Dowex was reduced by these co-ions especially by the sulphate (compared to removals in the presence of $\mathrm{P}$ and $\mathrm{S}$ (Fig. 5). Consistent with this data the sulphate adsorption was many times higher than phosphate adsorption (Fig. 6). The phosphate removal was higher in this $\mathrm{N}+\mathrm{P}+\mathrm{S}$ solution (Fig. 6) compared to the $\mathrm{N}+\mathrm{P}$ solution (Fig. 5). This may be due to the increase in iron concentration in the solution when sulphate was present. The iron concentration rose from $1.25 \mathrm{mg} / \mathrm{L}$ to $8 \mathrm{mg} / \mathrm{L}$ when the sulphate ion was added to the $\mathrm{N}+\mathrm{P}$ solution. The phosphate ions formed $\mathrm{FePO}_{4}$ precipitate in solution/or surface precipitation at the surface of the stainless steel electrode as discussed in sub-section 3.5.1. The reason for the higher Fe concentration in the $\mathrm{N}+\mathrm{P}+\mathrm{S}$ solution was due to higher electrical conductivity produced by the higher $\mathrm{N}+\mathrm{P}+\mathrm{S}$ ion concentration (conductivity $793 \mu \mathrm{S} / \mathrm{cm}$ for $\mathrm{N}+\mathrm{P}+\mathrm{S}$ compared to $465 \mu \mathrm{S} / \mathrm{cm}$ for $\mathrm{N}+\mathrm{P})$. Unlike phosphate, sulphate does not form a precipitate with iron and therefore no notable change occurred in the sulphate removal for this solution compared to the $\mathrm{N}+\mathrm{S}$ solution. 


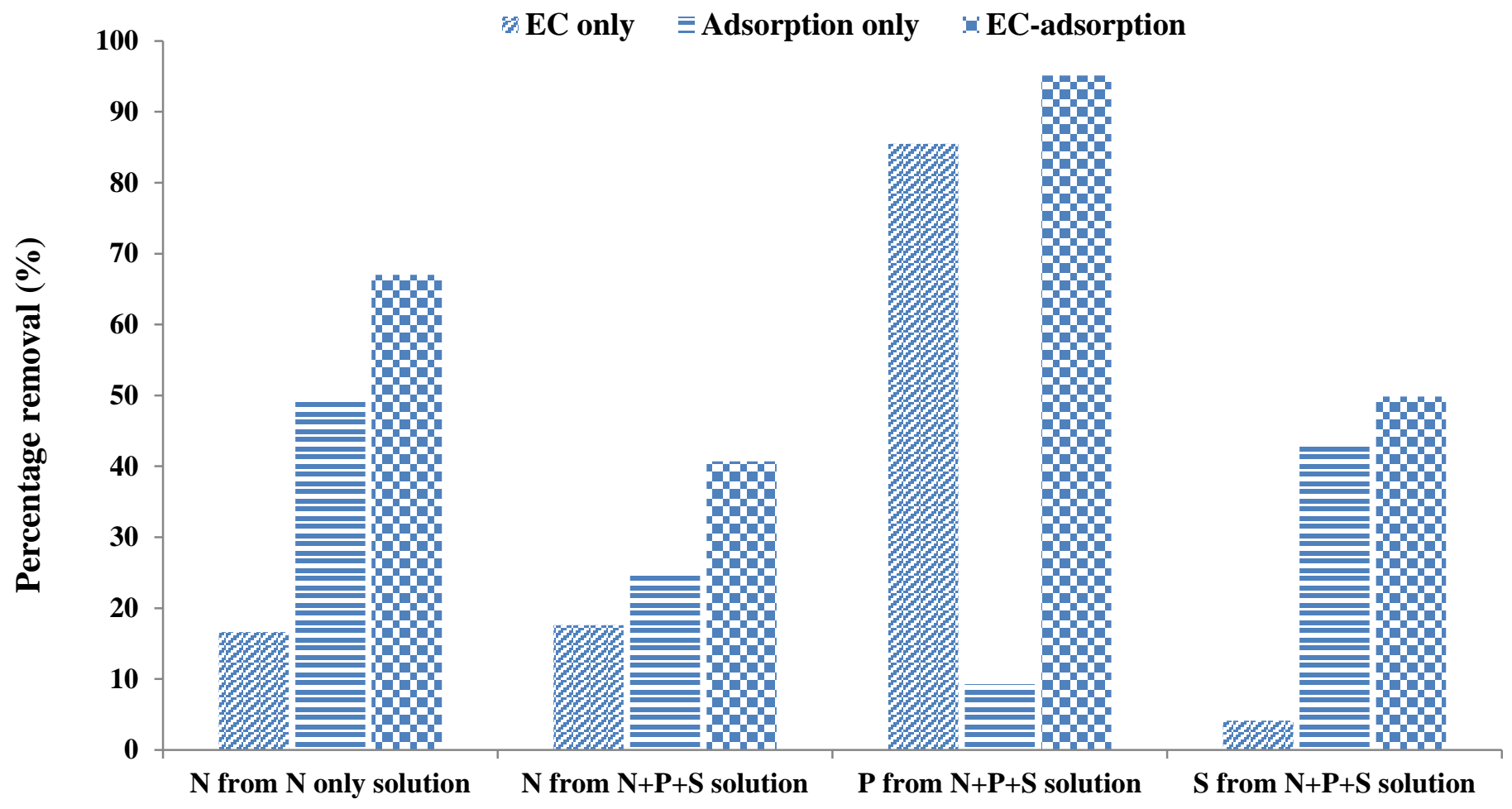

Ions

Fig. 6. Percentage of nitrate, phosphate and sulphate removed from the solution containing nitrate ( $20 \mathrm{mg} \mathrm{N} / \mathrm{L})$, phosphate $(5 \mathrm{mg} P / \mathrm{L})$ and sulphate $(50$ $\mathrm{mg} \mathrm{S} / \mathrm{L})(\mathrm{N}+\mathrm{P}+\mathrm{S}$ solution) and nitrate only (20 mg N/L) (N only solution). 


\subsubsection{Cost calculation}

Cost is an important factor in the water treatment process. Removing more pollutants at lower cost is preferred. Approximate cost calculations were made for the EC, adsorption and integrated (EC-adsorption) systems separately using the results obtained in the experiments. The cost of electricity in the EC system was assumed to be $\mathrm{A} \$ 0.30$ for $1 \mathrm{kWh}[32]$ and that of Dowex was $\mathrm{A} \$ 50 / \mathrm{kg}$ [33]. The costs of removing $1000 \mathrm{mg} \mathrm{N}$ from the nitrate solution were calculated and found to be $\mathrm{A} \$ 4.3, \mathrm{~A} \$ 5.5$, and $\mathrm{A} \$ 5.1$ for $\mathrm{EC}$, adsorption, and EC-adsorption, respectively (Table 1). The EC system's $\mathrm{N}$ removal efficiency was low compared to the adsorption system but the cost to remove $1000 \mathrm{mg} \mathrm{N}$ was also less in the EC system. However, the cost in the adsorption system can be reduced if the resin is regenerated and repeatedly used. Alternatively, low-cost adsorbents such as surface modified agricultural wastes can be used to reduce the cost of the adsorption system and still maintain the high nitrate removal efficiency [31]. Similarly, the integrated system cost can be reduced if the resin is regenerated or low-cost adsorbents are utilised. The costs for removing $1000 \mathrm{mg} \mathrm{N}$ as nitrate in the presence of sulphate and phosphate were $\mathrm{A} \$ 2.7, \mathrm{~A} \$ 10.4$, and $\mathrm{A} \$ 8.3$ for EC, adsorption, and ES-adsorption systems, respectively. By adding these co-ions, the current could be maintained at the same value of 1 A at a lower voltage in the EC system, and therefore less power would be consumed and this reduced the cost of the EC system.

Conversely, in the adsorption system the presence of phosphate and sulphate reduced nitrate adsorption and therefore the cost to remove $1000 \mathrm{mg} \mathrm{N}$ increased. In the case of the ECadsorption system, the cost of EC partly decreased while that of adsorption increased much more than the cost fell in the EC part of the EC-adsorption system. A cost calculation was done for the removal of $1000 \mathrm{mg} \mathrm{N}$ in order to compare the processes, though it is difficult to remove $1000 \mathrm{mg} \mathrm{N}$ by the EC method using a single EC cell (one cathode/one anode). Multiple cells are required to achieve this amount of removal and doing so will increase the operational costs. 
This suggests that an adsorbent needs to be added to the EC system (integrated EC-adsorption system) to achieve the highest removal of nitrate in a shorter period of time. The simple cost calculation made here demonstrated that the integrated system of removing nitrate could be a cost-effective process.

\section{Table 1}

Cost calculation for (A) EC system (B) adsorption system and (C) EC-adsorption system (1 $\mathrm{kWh}=\mathrm{A} \$ 0.30 ; 1 \mathrm{~kg}$ Dowex $=\mathrm{A} \$ 50)$

(A)

\begin{tabular}{|c|c|c|c|c|c|c|c|c|}
\hline Experiments & $\begin{array}{l}\text { Current } \\
\text { (A) }\end{array}$ & $\begin{array}{l}\text { Voltage } \\
\text { (V) }\end{array}$ & W & $\begin{array}{l}\text { Time } \\
\text { (h) }\end{array}$ & $\mathrm{kWh}$ & $\begin{array}{l}\text { Cost } \\
(\mathrm{A} \$)\end{array}$ & $\begin{array}{l}\text { N removed } \\
(\mathrm{mg})\end{array}$ & $\begin{array}{l}\text { Cost for } 1000 \\
\text { mg N removal } \\
(\mathrm{A} \$)\end{array}$ \\
\hline $\mathrm{N}$ only & 1 & 30 & 30 & 3 & 0.09 & 0.027 & 6.34 & 4.3 \\
\hline $\mathrm{N}+\mathrm{P}+\mathrm{S}$ & 1 & 18 & 18 & 3 & 0.054 & 0.016 & 6.08 & 2.7 \\
\hline
\end{tabular}

(B)

\begin{tabular}{lllcc}
\hline \multirow{2}{*}{ Experiments } & Adsorbent & Adsorbent & N removed & Cost for 1000 mg \\
& used $(\mathrm{g})$ & $\operatorname{cost}(\mathrm{A} \$)$ & $(\mathrm{mg} \mathrm{N})$ & N removal \\
\hline $\mathrm{N}$ only & 2 & 0.1 & 18.12 & 5.5 \\
$\mathrm{~N}+\mathrm{P}+\mathrm{S}$ & 2 & 0.1 & 9.62 & 10.4 \\
\hline
\end{tabular}

(C)

\begin{tabular}{llllll}
\hline Experiments & $\begin{array}{l}\text { EC cost } \\
(\mathrm{A} \$)\end{array}$ & $\begin{array}{l}\text { Adsorbent } \\
\text { cost }(\mathrm{A} \$)\end{array}$ & Cost $(\mathrm{A} \$)$ & $\begin{array}{l}\mathrm{N} \text { removed } \\
(\mathrm{mg} \mathrm{N})\end{array}$ & $\begin{array}{l}\text { Cost for 1000 mg } \\
\text { N removal }\end{array}$ \\
\hline $\mathrm{N}$ only & 0.027 & 0.1 & 0.13 & 24.72 & 5.1 \\
$\mathrm{~N}+\mathrm{P}+\mathrm{S}$ & 0.016 & 0.1 & 0.12 & 14.06 & 8.3 \\
\hline
\end{tabular}




\section{Conclusions}

The integrated EC-adsorption system removed more nitrate compared to the adsorption and EC systems when they were operated separately. Of the four distances $(0.5 \mathrm{~cm}, 1 \mathrm{~cm}, 2 \mathrm{~cm}$ and $3 \mathrm{~cm}$ ) between the electrodes, $1 \mathrm{~cm}$ was found to be the most cost-effective. The optimum nitrate removal (67\% from solution containing $20 \mathrm{mg} \mathrm{N} / \mathrm{L}$ ) was achieved for the integrated system at $\mathrm{pH} 7$ with the conditions where electrodes were $1 \mathrm{~cm}$ apart at $1 \mathrm{~A}, 30 \mathrm{~V}$ and $30{ }^{0} \mathrm{C}$ for Dowex. There was no significant change in nitrate removal efficiency in the EC system and integrated system in the presence of sulphate and phosphate. Ammonium ions were found in the EC system due to the reduction of nitrate at the cathode. However, their concentration was lower in the integrated system due to the release of $\mathrm{Cl}^{-}$ions from the adsorbents by ion exchange with nitrate. The $\mathrm{Cl}^{-}$ions would have oxidised to $\mathrm{Cl}_{2} / \mathrm{OCl}^{-}$which reduced $\mathrm{NH}_{4}{ }^{+}$to $\mathrm{N}_{2}$. The integrated system can be operated over the long-term by adding larger amounts of adsorbents initially and later frequently to the stainless steel electrode box. This study was conducted with a single cell (one cathode and one anode) to demonstrate the suitability of the integrated system for nitrate removal. It is recommended that future studies use multiple cells connected in series to continuously and more efficiently remove nitrate.

\section{Acknowledgement}

This study was financially supported by the Cooperative Research Centre for Contamination Assessment and Remediation of the Environment (CRC CARE) (project number 4.1.17-13/14). 


\section{References}

[1] G. Chen, Electrochemical technologies in wastewater treatment, Sep. Purif. Technol. 38 (2004) 11-41.

[2] K. Rajeshwar, J.G. Ibanez, Environmental electrochemistry: Fundamentals and applications in pollution sensors and abatement, Academic Press, 1997.

[3] T.A. Pressley, D.F. Bishop, S.G. Roan, Ammonia-nitrogen removal by breakpoint chlorination, Environ. Sci. Technol. 6 (1972) 622-628.

[4] A. Kapałka, L. Joss, Á. Anglada, C. Comninellis, K.M. Udert, Direct and mediated electrochemical oxidation of ammonia on boron-doped diamond electrode, Electrochem. Commun. 12 (2010) 1714-1717.

[5] S. Rubach, I. Saur, Onshore testing of produced water by electroflocculation, Filtr. Separat. 34 (1997) 877-882.

[6] A. Gürses, M. Yalçin, C. Doğar, Electrocoagulation of some reactive dyes: a statistical investigation of some electrochemical variables, Waste Manage. 22 (2002) 491-499.

[7] C.P. Poon, Electroflotation for groundwater decontamination, J. Hazard. Mater. 55 (1997) 159-170.

[8] B. Zhu, D.A. Clifford, S. Chellam, Comparison of electrocoagulation and chemical coagulation pretreatment for enhanced virus removal using microfiltration membranes, Water Res. 39 (2005) 3098-3108.

[9] T. Matsunaga, S. Nakasono, T. Takamuku, J.G. Burgess, N. Nakamura, K. Sode, Disinfection of drinking water by using a novel electrochemical reactor employing carbon-cloth electrodes, Appl. Environ. Microb. 58 (1992) 686-689.

[10] N.S. Abuzaid, A.A. Bukhari, Z.M. Al-Hamouz, Removal of bentonite causing turbidity by electro-coagulation, J. Environ. Sci. Health, 33 (1998) 1341-1358. 
[11] N. Bektaş, H. Akbulut, H. Inan, A. Dimoglo, Removal of phosphate from aqueous solutions by electro-coagulation, J. Hazard. Mater. 106 (2004) 101-105.

[12] C.Y. Hu, S. Lo, W. Kuan, Y. Lee, Removal of fluoride from semiconductor wastewater by electrocoagulation-flotation, Water Res. 39 (2005) 895-901.

[13] L. Joffe, L. Knieper, Electrocoagulation, Ind. Wastewater, (2000) 20-24.

[14] K. Bouzek, M. Paidar, A. Sadilkova, H. Bergmann, Electrochemical reduction of nitrate in weakly alkaline solutions, J. Appl. Electrochem. 31 (2001) 1185-1193.

[15] M. Da Cunha, J. De Souza, F. Nart, Reaction pathways for reduction of nitrate ions on platinum, rhodium, and platinum-rhodium alloy electrodes, Langmuir, 16 (2000) 771777.

[16] G. Dima, A. De Vooys, M. Koper, Electrocatalytic reduction of nitrate at low concentration on coinage and transition-metal electrodes in acid solutions, J. Electroanal. Chem. 554 (2003) 15-23.

[17] H.1. Li, D.H. Robertson, J.Q. Chambers, D.T. Hobbs, Electrochemical reduction of nitrate and nitrite in concentrated sodium hydroxide at platinum and nickel electrodes, $\mathrm{J}$. Electrochem. Soc. 135 (1988) 1154-1158.

[18] H.L. Li, J. Chambers, D. Hobbs, Electroreduction of nitrate ions in concentrated sodium hydroxide solutions at lead, zinc, nickel and phthalocyanine-modified electrodes, J. Appl. Electrochem. 18 (1988) 454-458.

[19] D. Reyter, D. Bélanger, L. Roué, Study of the electroreduction of nitrate on copper in alkaline solution, Electrochim. Acta, 53 (2008) 5977-5984.

[20] E. Lacasa, P. Cañizares, J. Llanos, M.A. Rodrigo, Effect of the cathode material on the removal of nitrates by electrolysis in non-chloride media, J. Hazard. Mater. 213 (2012) 478-484. 
[21] Y. Vanlangendonck, D. Corbisier, A. Van Lierde, Influence of operating conditions on the ammonia electro-oxidation rate in wastewaters from power plants (ELONITA ${ }^{\mathrm{TM}}$ technique), Water Res. 39 (2005) 3028-3034.

[22] K.W. Kim, Y.J. Kim, I.T. Kim, G.I. Park, E.H. Lee, Electrochemical conversion characteristics of ammonia to nitrogen, Water Res. 40 (2006) 1431-1441.

[23] M. Li, C. Feng, Z. Zhang, X. Lei, R. Chen, Y. Yang, N. Sugiura, Simultaneous reduction of nitrate and oxidation of by-products using electrochemical method, J. Hazard. Mater. 171 (2009) 724-730.

[24] M. Paidar, I. Roušar, K. Bouzek, Electrochemical removal of nitrate ions in waste solutions after regeneration of ion exchange columns, J. Appl. Electrochem. 29 (1999) 611-617.

[25] A. Shady, C. Peng, J. Bi, H. Xu, J. Almeria, Recovery of $\mathrm{Pb}$ (II) and removal of $\mathrm{NO}_{3}{ }^{-}$ from aqueous solutions using integrated electrodialysis, eletrolysis and adsorption process, Desalination. 286 (2012) 304-315.

[26] M. Emamjomeh, M. Sivakumar, Electrocoagulation (EC) technology for nitrate removal, (2005).

[27] M. Uğurlu, Effluents by the electrocoagulation method, G. U. J. Sci., 17 (2004) 85-99.

[28] Y.J. Kim, J.H. Choi, Selective removal of nitrate ion using a novel composite carbon electrode in capacitive deionization, Water Res. 46 (2012) 6033-6039.

[29] M. Malakootian, H. Mansoorian, M. Moosazadeh, Performance evaluation of electrocoagulation process using iron-rod electrodes for removing hardness from drinking water, Desalination, 255 (2010) 67-71.

[30] M. Kalaruban, P. Loganathan, W. Shim, J. Kandasamy, G. Naidu, T.V. Nguyen, S. Vigneswaran, Removing nitrate from water using iron-modified Dowex 21K XLT ion 
exchange resin: Batch and fluidised-bed adsorption studies, Sep. Purif. Technol. 158 (2016) 62-70.

[31] M. Kalaruban, P. Loganathan, W. Shim, J. Kandasamy, H. Ngo, S. Vigneswaran, Enhanced removal of nitrate from water using amine-grafted agricultural wastes, Sci. Total Environ. 565 (2016) 503-510.

[32] Australian Energy Council, https://www.energycouncil.com.au/. Accessed on 15th November 2016.

[33] Sigma-Aldrich, https://www.sigmaaldrich.com/australia.html. Accessed on 15th November 2016.

[34] M. Li, C. Feng, Z. Zhang, S. Yang, N. Sugiura, Treatment of nitrate contaminated water using an electrochemical method, Bioresour. Technol. 101 (2010) 6553-6557.

[35] E.V. Filimonov, A.I. Shcherbakov, Catalytic effect of copper ions on nitrate reduction, Prot. Met. 40 (2004) $304-309$.

[36] E. Pérez -Gallent, M.C. Figueiredo, I. Katsounaros, M.T.M. Koper, Electrocatalytic reduction of nitrate on copper single crystals in acidic and alkaline solutions, Electrochim. Acta 227 (2017) 77-84.

[37] M.B. Sasson, W. Calmano, A. Adin, Iron-oxidation processes in an electrofloc culation (electrocoagulation) cell, J. Hazard. Mater. 171 (2009) 704-709.

[38] E. Lacasa, P. Cañizares, C. Sáez, F.J. Fernández, M.A. Rodrigo, Removal of nitrates from groundwater by electrocoagulation, Chem. Eng. J. 171 (2011) 1012-1017.

[39] G. Rana, A. Adhikari, T. Mandal, New primer generated bacterial mapping and biofertilizing potentiality assessment of pseudomonas sp. isolated from cow dung, (2014). 